\title{
Condition and Shaping of Student Personality in Educational Process Through Transpersonal Psychology Perspective
}

\author{
Alfaiz \\ STKIP PGRI Sumatera Barat, Indonesia \\ alfaiz@stkip-pgri-sumbar.ac.id \\ Ryan Hidayat Rafiola \\ STKIP PGRI Sumatera Barat, Indonesia \\ riyan@stkip-pgri-sumbar.ac.id
}

\author{
Rezki Hariko \\ Universitas Negeri Padang, Indonesia \\ hariko@konselor.org \\ Zulfikar \\ STKIP PGRI Sumatera Barat, Indonesia \\ zulfikar@stkip-pgri-sumbar.ac.id
}

\begin{abstract}
This article was the latest research in 2015 that collaborative with my colleague about student personality in educational process using perspective of psychoanalysis consist of id, ego and super ego and will discuss with my research in 2016 selftranspersonal psychology perspective. This research was conduct in 2015 was implemented to understand a student motive to behave in their educational process, the result that using 77 student as a sample was found that Ego aspect in student personality has very high level. The question, if their ego was very high level so there is some disturbance in their social educational process, such individualist, lack of altruistic and lack of team work. In this time, education not only talk about cognitive but more than that, just like my previous article about education "It shape a ability of human being such cognitive, affective, conative, and psychomotor in the conciousness and logical process", that is important impact with global education connection with ASEAN Economic Community (AEC), this because educational process only came through understanding about them (student) self through transpersonal psychology perspective. So this article will discuss further about condition and how to shaping student personality through transpersonal psychology perspective and approach in counseling with point of view a logic of self, self as conciousness, and self realization in social educational process.
\end{abstract}

Keywords: educational, psychosynthesis, personality, transpersonal psychology, condition and shaping

\section{INTRODUCTION}

In educational process, we all know shaping a personality is the center of attention that has always been a major mission for educators, as well as for other experts focused on human studies. Until now, personality becomes a thing that always studied, it is indeed familiar because personality is a determinant of culture of a society. And personality simultaneously is also the result of the culture itself when. The culture has been passed on to the next generation.

This would be logical if linked between education, personality and culture. In the other side of education is the process of forming human personality, and culture is the result of human reason, value, and skill which is the manifestation of their personality all of which originates from the educational process. In other words education is a cultural process for human beings.

Therefore, the Association of Psychology America (APA) makes rules and guidelines for education to run according to human needs in accordance with the culture that suits them. The Six Multicultural Guidelines are designed to help psychologists understand how multicult ural issues affect us in very profound ways when dealing with individuals who are different from ourselves.

The main points of these Guidelines are: (1) awareness of one's own attitudes and beliefs that may have been shaped by one's culture; (2) sensitivity to the worldviews of ethnically and racially different individuals; (3) the incorporation of multicultural perspectives in education; (4) cultural sensitivity when conducting research on ethnically, linguistically, and racially different individuals; (5) the application of culturally appropriate skills in conducting applied psychological practices; and (6) applying multicultural perspectives in organizational change processes [2].

It is explained that the learning in accordance with the understanding of psychology that consciousness that our attitude and beliefs have been shaped by a particular culture, ethnicity and race sensitivity will make individual differences, there should be the incorporation of the views multicultural in actuation of education. These are some of the points that are fundamental to implementing the educational process with due regard for cultural background, and ethnicity which is the fundamental basis for human beings to be educated.

This basic base starts from the family culture of the learners, because the first education of the human is their own family. For a homogeneous culture as well as the location of research sample in this thoroughly a homogeneous culture such Minangkabau cultural. However, their family culture/character varies, thus forming a diverse personality in the educational process.

Personality is a psychological aspect which needs to be formed of education at the present time not only in terms of mindset, attitudes, and skills alone but also how the individual to be able to dialogue with themselves and realize that dialogue into their social activities, it is known with intrapersonal and interpersonal in study of social psychology. However, in this research, the focus to reveal the personality conditions of subjects in poin of view from the perspective of psychoanalysis.

According to Freud the model of personality structures that dialogue within the self-forming personality of his personality such Id, is the energy of sexual drive and aggressive that is not logical associated with irregular desire. Super ego, as a 
counterbalance that is the source of idealism (such as culture and religion). Ego, a structure that seeks to balance between inner and outer realities on the basis of reality [4].

Personality structure of the human person is always in dialogue when they want to behave in a social environment, good people behave in social life in perspective of psychoanalysis was individual awareness of reality themselves inside and outside of ourselves must be balanced. So the act does not violate the rules of existing culture. In the development of psychology the personality concept of Freud may have been criticized by many psychologists.

Rationally and logically, however, human beings are unconsciously engaged a dialogue in the good while doing small activities such as eating, drinking, sleeping, how to complete schoolwork, arranging the bedroom, even when doing heavy activities like doing two jobs in a short time, between preparing a presentation and taking care of family and work obligations in the office in this case the existence of multitasking. We unknowingly dialogue with ourselves or called the subconscious (Id), and confirm the need in ourselves with conditions outside the self that is (super ego) so that the ego will try to balance the options and try to reduce the risk of self-conflict with outside self. This applies to individuals who have the awareness and maturity of logic thinking.

Will cause problems if this can not be implemented by student who are still experiencing the stage of psychological development. While education in the present requires an attitude, values and ability of responsibilities. This is Regulation Number 12 Year 2012 Education Higher [3]. As well as the use of the 2013 curriculum which is a remarkable breakthrough for self-development of learners which of course begins with the development of personality. That attitude is a reflection of the maturity of the logical mindset and the emotions of learners (affective), as well as responsibility and skills are aspects (psychomotor) [1].

Therefore, to develop the personality of students, it is first necessary to identify the personality structure of the students. The question is the personality of the majority of students driven by the structure of Id, or Ego, or Super ego or the occurrence of conflicts in themselves? This will be discussed more deeply in this article based on the results of research with the preparation of instruments based on psychoanalytical theory which projection from each of these personality structures. And given the follow-up with paradigm of shaping personality with the transpersonal psychology approach such a psychosynthesis.

\section{Methods}

The population of the research was students in Public of Senior High School 5 Padang Indonesia, amounting to 329 learners spread into 10 parraler class. Therefore the authors use the technique of sampling by Proportional Random Sampling. A sampling of randomly and proportionally stratified population members, this sampling is performed when the population members are not similar [6]. To determine the number of samples in accordance with this study, the authors use the formula Taro Yamane [6] so that obtained a sample of 77 students.

Analysis of data that using in this research in accordance with the direction of research is to describe the personality traits of learners based on the perspective of psychoanalysis. Therefore, this time used the Sturgess criterion [5] by classifying the score interval and the achievement of respondents by transforming the score data into percentages. Through this can better describe the condition of the personality structure of the learners on each learner.

\section{RESULT}

Based on the description, explains that the description of the data classification score of each personality structure is seen collectively, in the table it is explain that the condition of students who have a Id drive 51 people from 77 sample, which is at high score interval. And for the Ego drive from 77 samples, 51 people who had ego at very high score interval level, and for the super ego from 77 samples there is 46 sample who were at high score intervals.

While to specifically see the personality conditions of 77 learners about the personality impulse seen from each students by comparing each achievement score of the instrument with the ideal score of each variable of the personality structure. So it is found in table 2, it is explain that every students has a id, ego and super ego drive, for they have a majority impulse in acting thus reflecting their personality. For high behaviorally driven students there were 36 samples from 77 samples, and 62 samples from 77 samples driven by a high ego and 35 people who were being drive by his super ego, and 28 that drive by ego Which is high and supported by id.

If seen specifically, students who act because of id and ego alone there are 14 people, driven by Id there are 3 sample, driven by the ego there are 13 sample, while in drove by the super ego there is 1 student, as well as in driven by the super ego and the ego of 15 students, and which is drive by the three aspects is 19 people and some who lack the strong impulse is 10 sample. This can be an important note, that of the 77 samples examined and has response a personality scale compiled in accordance with the characteristics of Id, Ego and Super Ego with the type of item specified to a scale of behavior in activity of the situation that conduct in item is intertwined between Id, Ego and Super Ego according to the formulation of Freud.

These results illustrate the personality traits of students viewed from psychoanalysis, each third condition of the personality structure has a negative excess in its implications with the educational environment. Therefore, it takes a shaping of paradigm to help condition the behavioral impulse of the personality structure to support the educational process. 


\section{Discussion}

The findings of this study describe the condition of personality encouragement of learners in accordance with the number of samples that have been specified. In table 2 is a specific description of the condition of each sample seen from the conditions of Id, Ego and Super Ego, it is obtained through the sample response to the item which has been arranged in such a way by emphasizing the statement in a situation that describes Id, Ego and Super Ego.

According to Freud, id is a basic impulse based on the pleasure principle impulse that does not make sense, and does not base on careful consideration. As for counterbalance and make balance the existence of super ego as rules and values outside the human self. And ego as a logical impulse and serves as a mediator between the world in the self (id) and the world outside the self (super ego). Based on this, explaining human behavior that reflects a good personality is a balance between id and super ego, this balance if only the ego has a good role in the human being.

Conditions experienced by learners as a sample of this study, 28 sample driven by the desire of his ego and supported by the id in the learning process, it has implications that the individual has less sensitivity to the environment. As Freud points out, the ego is a logical and problem-solving aspect [4], the individual who is driven only by the ego to satisfy the id, has an individualistic tendency in the learning process and tends to disregard the values. In addition, 28 samples are included into 62 students who have a high ego.

While studying in accordance with the government rules on the Curriculum of 2013 which emphasis on self-development and skills of students to prioritize the values and attitudes in cooperation. If this is achieved of course students can do good cooperation. However, these findings from 77 samples of the majority of students are driven by high egos regardless of whether they wish to satisfy the id or not. When compared with the number of students who ego and super ego are high there are 15 students, it also has negative excesses, that there will be a process of repressing their basic needs (id). The balance conditions that must be possessed by the students, this is only 19 students who have a good id fulfillment, logical ego fulfillment and appreciation of the super ego.

From these results, if the equilibrium of these three psychological drives is not achieve, the effort to help things get that from education to shape the character and personality uphold the values and attitudes achieved. Then there are some paradigms of transpersonal psychology with psychosynthesis approach. The study of psychoanalysis too narrows the study of human psychological analysis, that humans act because of the subconscious, while the consciousness obtained from outside the self is only in the subconscious that encourages people to act and behave. However, life experiences if not interpreted transcendently, experience will only be a sediment in memory. This has been combined by Asssagioli by combining peronality with transcendence personality. In accordance with the conceptualization that has been compiled before, here are some paradigms that can be applied in shaping the personality to be balanced in the learning process.

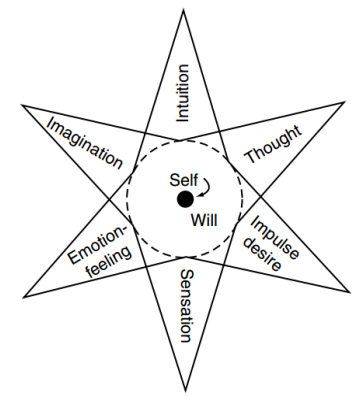

Figure 1

The Seven Functions of Personality

In the previous points it has been explained that in the view of psychosynthesis theory the personality function is divided into 7 which is a fraction of the 3 models of personality embodiment that is

Body / Body : : Sensation

Mind / Thoughts : Imagination, Intuition, Thought

Feeling / Feelings : Emotion, Impulse Desire, Will

These three models perform 7 personality functions reflecting from self ( $\mathrm{I}$ and $\mathrm{Me}$ ) in other words reflect the personality itself. In addition, "will" is an important aspect of the concept of psychosynthesis, this is because "will" is the energy assigned by self itself to act, regulate behavior and perform tasks according to the tendency of the personality function itself, if the individual has the "Mind", the will for the three personality functions will be maximized. Therefore, "will" be in the middle with self. Will energy of self and self is the personality structure of the counscious level consisting of (Figure 2): (1) the lower unconscious; (2) the middle unconscious; (3) the higher unconscious or superconscious; (4) the field of consciouness; (5) the conscious self or "I"; (6) the higher self; and (7) the collective unconscious [7].

In psychosynthesis, Assagioli explains to unconscious there are three levels namely: At the unconscious lower level which is the subconscious and impulse in Freud's "Id", at the unconscious middle level in analogy as in the present state of consciousness is called Freud preconscious, on the higher unconscious or superconscious represents the individual psychological future, the potential nature, aspirations, ideals, intuition, and spiritual experience, and the field of consciousness contains all consciousness, thought, feeling that observes all reality (super ego).

Self is the embodiment of the unconscious, conscious and superconscious of man and establishes the energy to act and behave in the belief of "will" by promoting which personality functions are the most dominant in the transcendent of the human self. In contrast to the simple psychoanalysis in understanding the human psychological urges that make up the structure of personality. Psychosynthesis is more detailed and transcendent in understanding human beings. 


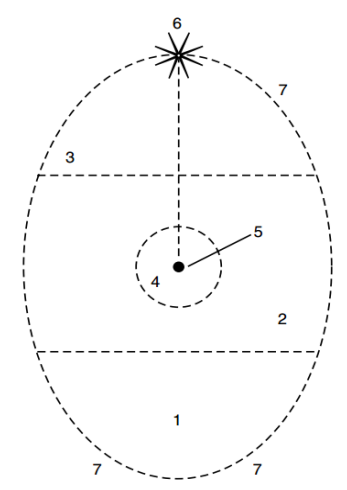

Figure 2

The Egg Diagram - Roberto Assagioli

Therefore, the important thing to reshape the personality traits of students through a psychosynthesis approach is to start from: (1) exploring the level of conscious / self awareness in the process of face to face counseling. In accordance with the egg diagram; (2) Determining the conscious level of students in accordance with the results of initial communication; (3) help recognize and reintroduce students to the most dominant personality functions within them; (4) focus to "will" as the student's energy to behave and act to achieve a higher level of consciousness with the emphasize the dominant of personality function in him; and (5) direct the conscious by considering the values and attitudes that need to be learned as a manifestation of understanding themselves transcendently, thus achieving an extraordinary experience of behaving and acting in the outside world.

\section{Conclusion}

The change of personality is seen from the attitude, mindset, and behavior in human social life. Nevertheless, personality changes not only from external factors such learning process in educational institutions, but the awareness of the need in knowing a self, the impulse to satisfy themselves and the need for satisfaction on the achievements of the advantages that we have. However, not all individuals make changes to themselves, this is because they are too attached to the conditions of the environmental (cultural) personality function that has been curbing and demanding that they have something in common with them.

This makes the need for counseling very high, and will not always be handled with an empirical approach. Therefore, it can be concluded that the approach of transpersonal psychology is needed in the 21 st century today. Through the approach of psychosynthesis which is one of the theories of transpersonal psychology that studies a human beings is not only empiricism, but also spiritual and transcendent nature of the human self.

\section{REFERENCES}

[1] Alfaiz. 2015. Peranan Self Efficacy sebagai Atribut Psikologi dalam Kesiapan Karir Mahasiswa pada Tingkat Perguruan Tinggi. International Conference on ASEAN Comparative Education Research Network (ACER-N), Malaysia.

[2] Constantine, M. 1998. Developing Competence in Multicultural Assessment: Implications for Counseling Psychology Training and Practice. The Counseling Psychologist, 6, 922-929.

[3] Dikti Curriculum Team. 2014. Undang-undang Nomor 12 Tahun 2012 tentang Pendidikan Tinggi. Jakarta: Minitry of Education and Culture.

[4] Kowalski, R., and Westen, D. 2011. Psychology. New York: John Wiley \& Sons.

[5] Mangkuatmojo, S. 2003. Pengantar Statistik. Jakarta: Rineka Cipta.

[6] Riduwan. 2005. Belajar Mudah Penelitian. Bandung: Alfabeta.

[7] Shorrock, A. 2008. The Transpersonal in Psychology, Psychotherapy and Counseling. New York: Palgrave MacMillan. 